\title{
Migrant Women and Politicized Experience: The Place of Gender in Three Social Organizations in Buenos Aires and La Plata (Argentina)
}

Femmes migrantes et politisation de l'expérience. La place du genre dans trois organisations sociales de Buenos Aires et de La Plata (Argentine)

Mujeres migrantes y politización de la experiencia. El lugar del género en tres organizaciones sociales de Buenos Aires y La Plata (Argentina)

\section{Sergio Caggiano}

Translator. Wendy Gosselin

\section{(2) OpenEdition \\ 1 Journals}

\section{Electronic version}

URL: https://journals.openedition.org/remi/14316

DOI: $10.4000 /$ remi.14316

ISSN: $1777-5418$

This article is a translation of:

Mujeres migrantes y politización de la experiencia. El lugar del género en tres organizaciones sociales de Buenos Aires y La Plata (Argentina) - URL : https://journals.openedition.org/remi/13844 [es]

Publisher

Université de Poitiers

Printed version

Date of publication: 1 December 2019

ISBN: 979-10-90426-65-8

ISSN: 0765-0752

Electronic reference

Sergio Caggiano, "Migrant Women and Politicized Experience: The Place of Gender in Three Social Organizations in Buenos Aires and La Plata (Argentina)", Revue européenne des migrations internationales [Online], vol. 35 - $n^{\circ} 3$ et $4 \mid$ 2019, Online since 01 January 2022, connection on 16 April 2022. URL: http://journals.openedition.org/remi/14316 ; DOI: https://doi.org/10.4000/remi.14316

This text was automatically generated on 16 April 2022.

(c) Université de Poitiers 


\section{Migrant Women and Politicized Experience: The Place of Gender in Three Social Organizations in Buenos Aires and La Plata (Argentina)}

Femmes migrantes et politisation de l'expérience. La place du genre dans trois organisations sociales de Buenos Aires et de La Plata (Argentine)

Mujeres migrantes y politización de la experiencia. El lugar del género en tres organizaciones sociales de Buenos Aires y La Plata (Argentina)

\section{Sergio Caggiano}

Translation : Wendy Gosselin

1 Although gender relations have always been a fundamental component of population movements, they have only attracted attention in recent decades, partly due to the impact of novel phenomena commonly interpreted as the "feminization of migration." The role women play in the social organizations of immigrants has also become a source of interest of late. This can be attributed, first and foremost, to the new focus on gender relations and women's role in processes associated with human mobility, but also to the fact that immigrant organizations have gradually incorporated gender issues into their agendas.

2 In this article, I explore the integration of gender issues by immigrant women's associations in Argentina in the first years of this century. The analysis reveals the persisting heuristic potential of an old feminist tenet: the connection between the personal and the political. My specific question relates to the ways in which gender is politically articulated within the experiences of immigrant women. I thus explore how the experience of gender relates to the institutionalization of this experience, considering that migration studies addressing gender issues rarely question this 
relationship. The main objective of this article is to reveal the different levels in which experience is formulated as political and the complexity its articulation entails.

Before providing a description of the organizations examined as part of the fieldwork that informs this article, the second section briefly reviews the academic debate on experience in order to highlight the challenges this concept entails. In this analysis, I hope to avoid the question of how experience relates to language-a debate that is, as I will show, settled. The facet of this debate that deserves more attention-one often erroneously appended to the question of experience and language-is that of the connections between personal experiences of inequality and their integration to organizational and institutional agendas. The third and fourth sections provide an overview of the three women's associations examined in my fieldwork, describing their objectives, activities, institutional frameworks, and alliances with agents at other levels (international organizations, NGOs, and state agencies). The connections between the personal and the political go both ways, as seen in the fifth and sixth sections: activism affects gender experiences and gender experiences affect activism. Finally, the section "Politicizing Experience and the Dialectic between the Personal and Political" draws attention to the multiple aspects of life that can be politicized and are inextricably bound. Experience is politicized at different levels: at home, within political organizations, on the streets, within a state or supra-state institution. Politicization, then, can serve as an analytical entry point for understanding how positions like those of migrant woman, Bolivian, poor worker, mother, and others coexist, forming assemblages and hierarchies. Finally, in addition to summarizing the contributions of this article, the conclusions present three implications for the study of intersectionality and inequalities that come with acknowledging the levels of politization of experience (Stolcke, 1992; Davis, 2008).

\section{The Political Meaning of Experience}

4 All experience carries meaning. Meaning is social. And there is no meaning in our social lives that is not bound to our experiences. Therein lie both the force and weakness of different perspectives that strive to attribute political, public meaning to any phenomenon. Experiences condense meanings and meanings are produced in multiple ways, thus shaping experiences in a process that is one and the same. The materials employed in this process are heterogeneous, as are the mechanisms at work in attributing meaning. Another aspect of experiences and their meanings is that they are configured on several different but often connected levels. This is the linchpin of this article.

5 The different levels in which experiences and their meanings take shape range from daily interactions to bureaucratic regulations and systems, from the intimate to the public realm, from family to state. Each person will learn, unlearn, or question gender positions when participating in the preparation of foods and their distribution and consumption in the home; when getting involved in collective demands for rights; and when participating in a range of social and institutional spheres. All involve knowing how to talk, look, dress, move, and inhabit the space, understanding what one can or cannot wish for or aspire to, etc.

6 Lengthy theoretical discussions on experience have shed light on substantial aspects of the problem but left others in the shadows. One misconception with fundamental 
repercussions is that of reducing the difference between the levels of experience and meaning to the difference between language/non-language. For example, hooks assumes that different levels exist, at least to a certain extent, when she observes that "people who are truly oppressed know it even though they may not be engaged in organized resistance or are incapable to articulate in written form the nature of their oppression" (2000: 11). Yet separating the truth of oppression from its writing is flawed. Similarly, Jay describes experience "at the nodal point of the intersection between public language and private subjectivity" (2005: 6-7). Though this hints at the different levels, it reifies the public/private division and leads to a misconception similar to that of hooks, assuming that language is limited to the public realm (when it is obvious that inner life in the Western hemisphere-be it modern or postmodern, confessional, psychoanalytical, or any other-cannot be conceived without language) and that within that public space, there is only language (without considering images, bodies, or the use of the space).

7 In a later work, Jay himself discusses both the conservative outcomes of invoking experience and the search by Marxist theorists for a politics of experience. An illusion of immediate-that is, unmediated-experience, persists in both, says the author (Jay, 2005). Within the feminist debate, Scott reviewed the problem in "Experience" (1992), a text included in a collection of works by feminist scholars that marked a milestone, but also sparked new controversies. One of Scott's main arguments is that the use of experience as indisputable evidence hinders the critical history of difference, leading her to reject the separation "between 'experience' and language," (Scott, 1992: 34). However, her affirmation that "experience is a linguistic event" (Scott, 1992: 34) provoked fiery criticism that she was reducing experience to language.

One of the scholars to react to Scott's affirmations, Alcoff, makes a critical contribution by considering other materials that help build meaning from experience. This author is focused on "the role of bodily experience in the development of knowledge" (2000: 251). In this regard, Alcott notes that "experience sometimes exceeds language," and is, thus, "inarticulate" (256). In the author's reinterpretation of Meleau-Ponty, this means that "Meaning and knowledge are not locked into language, but emerge at the intersection between gesture, bodily experience, and linguistic practice" (261). Alcoff proposes to understand "experience and discourse as imperfectly aligned with locations of disjuncture" (256). In a similar sense, Stone-Mediatore (1999) follows Mohanty in noting the tensions and mismatches between experience and language. However, both Alcoff's imperfect alignment and Stone-Mediatore's tensions/ mismatches pose a problem: the only alternative to reducing experience to language appears to be separating the two.

9 An additional assumption is necessary to clarify the relationship between experience and language: experience need not be dissociated from a signifying material-verbal language-in order to consider all of its dimensions. Once this is established, it becomes possible to explore how other materials and logics of meaning participate in making sense of experience. "Language is not exclusive material, nor is it the only place of meaning," (Elizalde, 2008: 25). Experience in general-and gender experience in particular-is constructed from multiple materials and ways of producing meaning. Verbal, oral, and written language is involved, of course, as is-as Alcoff notes-the body. In other words, experience also depends on how we learn to move our bodies socially in space and in relation to other bodies (Guillaumin, 1992) both human and 
non-human (Navaro-Yashin, 2009). It is bound to how we look at things, and on seeing and being seen (Mira, 2003), often through prosthetic devices (Haraway, 1988) and on how we interpret the repertoires of images in our surroundings (Caggiano, 2012b, Smith 1999; Poole, 2000). Different materials and logics simultaneously come into play as experience is configured. The fundamental difference is not between an immediate level of experience and its deployment in language: there is no experience zero degree but instead, an amalgamation of words, images, and corporeal sensations.

10 This is another debate that has already been put to rest. The purpose in briefly addressing it here is to avoid confusion with an issue that merits greater attention: the social levels where experiences and meanings are configured. When we sense that one way of manifesting experience (a statement, an image, a gesture) does not suffice, it is not because it lacks a pristine, immediate, essential, or ineffable background but because it does not line up (being "imperfectly aligned" or "mismatched") with other possible manifestations.

11 On the different levels where experiences and meanings are configured, different actors participate, each with their own specific interest. One question Scott poses - "what counts as experience and who gets to make that determination," (Scott, 1991: 34)-still begs an answer, but not to argue the question of language. The persisting challenge is to examine the specific actors and their different levels of power, the degree of institutionalization of their demands, the scales of action, and the unequal capacities of the different actors in terms of maneuvering the different levels. The question as to why these asymmetries enable some experiences but not others, stabilizing some histories but not others, defining needs, and conditioning "forms of social engagement and participation, and [...] the construction of claims about belonging," (Yuval-Davis et al., 2005: 530) poses an additional challenge. This is always an open field where other histories trickle in, possibly enabling other experiences.

\section{Immigrant Women, Social Organizations, and Gender}

12 Gender relations are a constitutive part of migratory processes (Sassen, 2003) and play a central role in the configuration of identities, practices, and the institutions that influence them (Donato et al., 2006). Men and women are affected differently by the socioeconomic and political conditions of their countries of origin, and this results in the gendering of migratory patterns. Gender is also a prominent part of the norms, policies, and day-to-day interactions that make up an immigrant's incorporation into the host country, and affects men and women in different ways (Piper, 2006). Immigration often leads individuals to reconsider certain aspects of life that they formerly took as a given (Schnapper, 1988) and in this regard, "when men and women migrate internationally, they are confronted with alternative gender ideologies, institutions, and practices" (Pessar, 2005: 6).

Despite this importance, as noted earlier, immigrant organizations have only recently incorporated gender issues to their agendas. According to the few existing studies on immigrant associations in Argentina, cultural and religious associations were the most common until the first years of the twenty-first century, followed by sports and social organizations (IOM-CEMLA, 2004; INDEC, 2003). The literature does not name a single organization dealing with gender issues. In terms of the membership of these associations, men are the majority in over half, while women are the majority in just 
17.4\%. With regard to leadership posts at immigrant organizations, men also predominate, holding $77.4 \%$ of board positions. This finding coincides with studies on immigrant organizations in other countries. Although women are becoming increasingly visible in these groups (Kuah-Pearce y Hu-Dehart, 2006), scholars have noted how they are at a disadvantage compared to the men: they have less time available to participate and are underrepresented in decision-making and leadership roles (Goldring, 2001; Low, 2006; Chung, 2005).

In the mid-aughts, however, immigrants had begun configuring certain demands from a gender perspective (Magliano, $2009 \mathrm{y}$ 2013), though not at the level of the organizations. Children-often the motivation for migrating and for staying at a jobtended to be immigrant women's biggest concern, along with the time they had to be away from them and the question of childcare, which generally required cooperation with other women in Argentina (or in their country of origin, for that matter). This took its toll on women. Within the cultural, sports, or ethnic-national grammars that provided a framework for conflict within traditional organizations, however, there was no room for politicizing gender relations. These particular forms of unease and suffering that distance and context impose on immigrant women are political, or could be, yet these were not on the agendas or among they rights they sought to define or protect in those years.

In this context, and in a way similar to what occurs in countries like Spain (Pérez, 2004) or France (GRDR, 2016), associations specifically for immigrant women began to spring up in the first decade of the new century. Women came together in these organizations to discuss the specific issues they faced as immigrants. While many adopted a gender lens, some existing associations amended their profiles to also consider this perspective. The fact that these demands came to a head is often explained by the growing numbers of women in migrant flows, and by the "greater social and political visibility of the figure of the immigrant woman," (Magliano, 2013: 166). At the same time, in order to understand this visibility, it is important to consider the influence of U.N. organizations like International Organization for Migration (IOM), the United Nations Population Fund (UNFPA), the United Nations Development Fund for Women (UNIFEM), global NGOs and state agencies at different levels that have engaged in dialogue with these entities. On the whole, these have helped expand a language of gender while building a women's agenda with a focus on migration. When viewed from this perspective, the notion of the feminization of migration-a factor often cited as explaining the phenomenon-becomes more of a symptom of the international circulation of categories and concepts that configure it. ${ }^{1}$

In their dialogue with these agencies, immigrant women have discovered an opportunity and a framework to organize themselves in new ways. The three associations that will be described herein show similarities and differences in terms of classifying the migratory experience of women. The first two organizations that will be presented are the Civil Association of United Immigrant and Refugee Women in Argentina (AMUMRA), ${ }^{2}$ and Q'amasan Wuarmi ("women's strength" in Quechua), both of which structure their needs and demands in terms of gender. The third association, a community soup kitchen established by the Unemployed Workers' Movement (MTD), brings together immigrant women who are also "unemployed workers," and organizes their struggle for the recognition of social rights and access to employment and resources. ${ }^{3}$ 


\section{Gender in Immigrant Women Associations and in an Organization of Unemployed Workers}

AMUMRA is a non-profit organization officially established in 2005, though its roots go back to associations founded in the 1990s that later dissipated. The organization as it currently exists began taking shape after the U.N. World Conference against Racism, Racial Discrimination, Xenophobia and Related Intolerance, held in Durban in 2001. UNIFEM provided key support, allowing one of the women who would become a leader at the association-as well as other members-to attend the conference. AMUMRA does not have any paid staff and the number of collaborators, and intensity of their involvement, has varied over time. Thanks to the sponsorship and funding from UNIFEM, the association has offered sexual and reproductive health training and violence prevention for poor immigrant women in Buenos Aires and the metropolitan region.

As for Q'amasan Wuarmi, this association of Bolivian migrant women has also experienced peaks and valleys that can be attributed to the institutional ties its members have forged over the course of its existence and until 2013. The permanent coordinator of the group notes how the discrimination she had witnessed led her to make a radio announcement inviting Bolivian women to come together in mid-2000. As a result, the May 27th mothers' center (Centro de Madres 27 de mayo) was born, taking its name from Mother's Day in Bolivia. Later, when the Argentine government began offering assistance to housing cooperatives that provide opportunities for low-income earners, the women in charge of the center began the paperwork to become a cooperative. In 2007, they joined forces with Bolivian women from other small groups to form Q'amasan. Through their personal ties with members of Evangelical churches, they were put in touch with the Argentine Committee for Refugee Support (Comisión Argentina para Refugiados y Migrantes, or CAREF $)^{4}$. This, in turn, let to connections with the United Nations Population Fund and efforts to promote the sexual and reproductive health of immigrant women.

19 In terms of their ties to international organizations, these associations have two features in common. The first is an emphasis on rights and a concern with a gender perspective, which both AMUMRA and Q'amasan build in a sustained dialogue with the organizations mentioned above, and with other NGOs and government agencies. Though the women are proud of their work with the international organizations and the stimulus they receive, their collaboration is not free from tension. In the case of AMUMRA, there is some discontent and dissatisfaction over issues they have not been able to address. Basically, the organization has yet to design a long-term agenda of its own precisely because the need for funding requires constant work to submit shorter projects and proposals to international or state agencies. For the Q'amasan women, the language of rights that activists espouse when the topic at hand is gender prove tricky when have to address the work conditions of small and medium-sized immigrant-run sweatshops accused of worker exploitation. Their expertise in the language of gender is evident when they speak of women as "the weakest link on the textile chain," because she is "so flexible," and "an object of desire but also a workhorse," (Sabina, Bolivian, age 52, 25 years in Argentina, 20125). However, they refuse to allow legal professionals to intervene when the informal sweatshops are raided because, as the activists note, 
they would trick the men and women running the machines into saying they are victims of oppression.

The second feature both organizations share has to do with the importance of nationality. International organizations work to bring together women from different countries and regions, subordinating or relegating national or ethnic identifications in favor of their experience as immigrant women. In AMUMRA, although the organization's leaders agree with this in theory, it has been a cause of dissatisfaction and even resistance. The women of Q'amasan, which was founded as a Bolivian association, see this proposal by international organizations to set aside national origin as strategically erred, despite the good intentions behind it. In their opinion, nonBolivians cannot "come into that little place where a Bolivian woman confides in her peers," (Sabina, Bolivian, age 52, 25 years in Argentina, 2012). That was Sabina's way of saying that the approach of the international organizations did not take into account how nationality is a factor in interpersonal proximity.

21 The third organization is a soup kitchen run by the MTD, located in the neighborhood Altos de San Lorenzo in the city of La Plata. ${ }^{6}$ The local branch of the MTD, a multisectoral movement founded in 2004, runs community soup kitchens in outlying neighborhoods. By cultivating ties with state officials, it also serves as a mediator for social welfare and spots in the job programs the government offers. In Altos de San Lorenzo, the movement also oversees two community gardens where beneficiaries of the Argentina Trabaja program work.?

In 2004, the composition of the soup kitchen was relatively balanced in terms of nationality (Argentine and Bolivian), gender (with women of both nationalities and Argentine men). But gradually, by encouraging new members to join, the family and transnational networks connecting immigrants already in Argentina with Bolivians intending to migrate in the near future led to an overwhelming majority of Bolivians at the MTD soup kitchen. Collaborators are expected to attend events not specifically related to the soup kitchen like marches, meetings, and assemblies, and also have the chance to join one of the garden crews and thus earn a salary.

Rodrigo explains that activism on the part of soup kitchen participants and the movement itself promotes the classification-in the Bordieuan sense of enclassement-of Bolivian migrants. The women voice demands for economic and social rights from their position as unemployed women workers, a figure with a certain degree of institutional legitimacy in the society in which they now reside. By adopting this position, they also mitigate the discrimination associated with being a foreigner in Argentina. This does not mean that nationality ceases to be relevant for these women-or for the Argentine women and men who oversee the soup kitchen's operations. "The practical and discursive mechanisms at work in classification processes partially emerge from-and act upon-a sociability based on ethnicity and nationality," (Rodrigo, 2018: 121-122).

National belonging is configured in the neighborhood before a woman joins the organization. The processes of reciprocal recognition "are less related to the possibility of rekindling or reconstructing symbols [and more related] to coping with fears, difficulties, expectations, and hopes," (Rodrigo, 2018: 98). The Bolivian-ness constructed in neighborhood experiences plays out in how Bolivian life is recreated there and in day-to-day relations. Unlike immigrant efforts to reaffirm nationality through flags and banners, Rodrigo notes how a pair of shoes can be relevant in building this kind of daily nationality. One of the women cited in his ethnography notes 
that in the city where she now resides, she recognizes fellow Bolivian women by their outfits-especially the shoes they wear. This is about an experience of Bolivian-ness, not (or not necessarily) about reaffirming ties to Bolivia.

This type of national belonging has taken shape because of the women who replicate it in the neighborhood, at the soup kitchen, and in the organization. The husbands, fathers, sons, and brothers of these women do not play prominent roles in reconstructing this specific nationality; they do not participate in the networks of daily relations or in the shared practices that sustain them. Some of the men are, however, involved in the type of immigrant associations that reaffirm Bolivian nationality; sometimes they are members of the board; and some have contacts with local unions as a result of their jobs, usually in construction. At the same time, like a sense of nationality cultivated within a neighborhood, that common feeling of class bears the gender markers of those who build it. The community garden crew, the soup kitchen, and more broadly, the MTD constitute shared spaces of empowerment with other women. Similarly, women share the workshops on unionism and cooperativism. Practices and relations that configure a class position are crisscrossed by their tastes, desires, urgencies, and concerns as women.

\section{Reinterpreting Life from a Gender Perspective} relations (Arizpe, 1987). Women's political interventions at meetings, assemblies, and protests, and their activism itself, reverberate behind the closed doors of the home, with myriad effects on personal and intimate bonds. The logics, languages, attitudes, and behaviors from the organizational realm can also play out here as well.

The context of the host country can intensify or guide this revision of personal gender relations, given that immigrants are forced to confront ideologies, institutions, and gender practices different from those in their country of origin. This invites reflection, as can be seen in this comment by one of the founding members of AMUMRA:

There [in Bolivia], men still have the idea that women are inferior and need to be managed. Men don't give women freedom there and we have to ask permission for anything we do. That's not the way it works here. (Lidia, Bolivian, age 44, four years in Argentina, member of a group that later became AMUMRA, 2005)

Participation in gender organizations often leads women to question power relations in the domestic sphere. It is common for activists in these groups to point out that the men-especially their husbands, but also their fathers or brothers-"don't like" their activism or are "bothered" by it. While some women resolve this by "asking their permission," others look down on this strategy, arguing that it reaffirms the place of power of the men. Sabina, from the organization Q'amasan, minces no words in this regard:

That's his problem [her partner's]. He doesn't agree with what I do but what do I care [...] because I like what I do and no one is going to take that from me. I'm going to keep at it. (Sabina, Bolivian, age 52, 25 years in Argentina, 2012)

29 A telling fact about Sabina-like another well-known member of Q'amasan-is that she is one of a small but growing group of single women who migrate to Argentina from Bolivia. Sabina came with friends after having a child on her own in La Paz; the other woman in the organization crossed by land from Southern Bolivia all by herself, 
arriving first to the border province of Jujuy before moving to La Plata. Among the AMUMRA leadership, there are also women who migrated from Peru or Paraguay without a romantic partner.

Given that AMUMRA and Q'amasan define their priorities in a dialogue with institutions and organizations that have expertise in the area, the language of gender is practically mandatory for getting involved. These women note, usually with pride, that at the personal and institutional level, activism has taught them a great deal about gender. One of the members of Q'amasan explains how rhetoric has been another important lesson: "We've learned a lot and even our discourse has changed. To some extent, you could say that the circumstances led us to become technical, theoretical" (Daisy, Bolivian, age 48, 25 years in Argentina, 2012).

31 Time is a factor that reveals the tensions that arise as women reinterpret life in terms of gender. The language of rights is a supranational perspective that the women of AMUMRA and Q'amasan have progressively incorporated to their statements and international alliances. This was something entirely new, not only with regard to the immigrant associations men had formed, but also in terms of the few existing women's associations, most of which were committed exclusively to social assistance. At the same time, as I noted earlier, national belonging continues to be an important organizational linchpin. In fact, it prevails in exchanges between the country of origin and country of residence, and is the razon d'être of a significant number of traditional immigrant associations. Q'amasan, in fact, maintained its identity as a Bolivian organization. AMUMRA, despite having a great number of Peruvians within its leadership, adopted the supranational perspective, leading to dissent and even abandonment by women who prioritized national belonging.

The story of Olivia is indicative of this dynamic. In Bolivia, Olivia has been sporadically involved with an NGO committed to human rights. She came to Buenos Aires in 2001, following a husband who had migrated eight years earlier while she stayed in Bolivia looking after their three children. Now that her children were older, she had more time for her activism in Argentina. She initially got involved with the Bolivian Human Rights Movement (Movimiento Boliviano por los Derechos Humanos), where several Bolivian professionals collaborated. Olivia is a lawyer but it took her 11 years to get her degree validated in Argentina. Her husband, who is a physician, "has always been involved in politics," in her words. By the time she arrived, he had started a Bolivian political organization in Argentina.

For over a year, Olivia was involved in the efforts to get AMUMRA off the ground, but she left to start a new civil association for Bolivians in Buenos Aires in 2005 after the association opted for the supranational approach. In those years, she remembers Bolivians working hard to get organized and how this led her to get increasingly involved in community activism. When President Evo Morales and his Movement for Socialism (MAS) party came to power in Bolivia, the issue of Bolivians abroad ranked high on the national agenda. The government began to strengthen bonds with "nationals abroad," its consulates and vice-consulates working more closely with Bolivian organizations abroad, particularly in Argentina, the country with the greatest number of Bolivians outside the country. The organization olivia founded helps Bolivian nationals with their documentation and labor rights. Later, when gender gained momentum thanks to UNFPA and other international organizations, increasing women's access to healthcare became another one of its initiatives. With the support of 
a Buenos Aires NGO, the association-and Olivia herself-produced a video denouncing labor abuses and the obstacles to healthcare access for immigrants, focusing specifically on the case of a young immigrant woman. The title of the video, Por ser boliviana (Because she's Bolivian), reveals that nationality plays a key role in the proposed explanations for class, gender, and generational inequalities.

For the Bolivian women of Altos de San Lorenzo, work at the soup kitchen allows them to participate in the gender struggle without causing a ruckus. Their reason for not being at home, in this case, is easier to justify, since it can be seen as an extension of what are commonly considered their responsibilities as mothers or wives. Despite this, their work at the soup kitchen redefines certain aspects of gender relations. Social bonds with other women promote critical approaches to household dynamics (Caldeira, 1987).

Some husbands are uncomfortable with their wives joining the movement because, in their view, they are shirking their female responsibilities and forcing a reorganization of household life to accommodate their activism. This attitude on the part of husbands reaffirms the gender activism of these women. The recognition of these women's legitimate political roles in the organization and, for those who join the work crew, paid employment, leads to a revision of the sexual division of labor, the home, and family relations. At the beginning, these women may not make gender-based arguments, but they at least begin redistributing their tasks and the time they spend on them. When an argument about their responsibilities inside and outside the home starts with a romantic partner, father, or both, the reasoning and concepts of the struggle for social and labor rights are transferred to the domestic sphere. Women defend their right to work and make their own money, as well as the recognition they obtain through the organization, in contrast to the idea that their activities come second to those of the men, or to unquestioned assumptions regarding what women should or should not do. Slowly, tensions begin to appear in relation to housework and the women start asking the men to lend a hand in the home.

Rodrigo (2018) notes two aspects of women's activism at the soup kitchen that also apply to the members of the other two groups. The first is that they interpret the home as a space of social isolation. Some of the women may have had this perception-or hints of it-before joining the movement, and this may be part of what motivated their activism. However, once this vision is shared with other women in the group, assessed, and refined at the conceptual level, it acquires greater intensity. For this reason, the struggle to emerge from the home in order to do these activities precedes the fight for resources or to obtain a job stipend. The other aspect of activism Rodrigo notes is the strengthening of their self-esteem that comes with participation, another motivation to break free from the social isolation of their homes. This is a process that depends on feedback; its origin is difficult to trace, but it clearly helps build self-confidence while fostering participation.

\section{Personal Experiences and Activism}

The personal and the political are so intertwined that when there is a change to either of the two, the other is necessarily affected. While the stories above have made it clear that women's activism affects gender experiences, these experiences have an unquestionable impact on activism as well. First, the way in which an immigrant's 
political involvement takes shape is "mediated by gender norms, expectations and opportunities for agency" (Piper, 2006: 134). The sexual division of labor conditions the spheres and forms of activism among immigrant women and men. Given that caregiving tasks generally fall to women, they are the ones who lead the struggle against restricted access to healthcare (Jelin, 2006) and education (Sinisi, 1998 and 1999); women also organize activities aimed at preserving and recreating their language and traditions (Low, 2006).

In the associations that predated AMUMRA and Q'amasan, activism can be seen as an extension of one's domestic responsibilities: getting an education for one's children in the case of AMUMRA and expanding caregiving networks for the ill in the case of Q'amasan. At the same time, for the women at the soup kitchen, the importance of marriage, the community weight of heterosexual partnerships, and the sexual division of labor that validates men's role as providers and women's role as caregivers jointly shape the idea that women "are at the soup kitchen as a way of 'helping' their husband," (Rodrigo, 2018: 134).

On the other hand, the women of AMUMRA and Q'amasan often remember personal experiences from the past that led them to join the association, like scenes of domestic violence or a mother who, as the head of the household, was obliged to work in order to provide for the family. Given the fact that involvement in these groups is seen as a lesson in the rhetorics of gender, the memories and accounts of these personal difficulties and corresponding decisions are filtered through this lens: "Ever since I was young, I've fought for women's rights." (Daisy, Bolivian, age 48, 25 years in Argentina, 2012). Experiences-including those in one's place of origin, family, romantic relationships, experiences as an immigrant, and work trajectory-are interpreted in terms of gender and the struggle for rights. A review of each woman's biography, then, reveals the impact of personal experiences on activism because this activism is, at the same time, affecting the way in which these experiences are perceived and narrated.

The aspects of personal life that foster social activism-some of which are unexpectedvary over time. Religious beliefs, when combined with a religious affiliation, can lead to gender activism, for example. As noted above, some of the Q'amasan members attended Evangelical churches, where they got involved in CAREF. CAREF led them to the UNFPA campaign and work group on sexual and reproductive health, and contact with the professionals and militant feminists in this space led them to get involved in the struggle for the sexual and reproductive rights of immigrant women.

41 Among the women at the soup kitchen, personal experience impacts activism in yet another way. When recounting their experiences as immigrant women, national and class belongings are defined in terms of gender. As noted above, the way in which these women rework nationality and class in the neighborhood and at the soup kitchen is not aligned with the meanings attributed to these concepts by either the men in their family or most of the immigrant associations. Nor does it coincide with what the leaders of the unemployed workers' movement expect of them.

The spheres of interaction of Bolivian women are built on personal terms. As a sense of belonging, Bolivian-ness is defined here by its situated, domestic character and "is connected to network building and daily involvement" (Rodrigo, 2018: 96). The informal meeting places fundamental for women's sociability in the neighborhood include places where food is sold or distributed and spaces where childcare is offered. Joint food and clothing purchases activate these networks. Childcare necessitates 
arrangements with family members, neighbors, and other Bolivian women. Childrearing and education serve as a touchstone for a family's overall performance, thus fostering both mutual assistance as well as competition. These spaces for neighborhood interaction give shape to a specific and vivid form of Bolivian-ness, one that allows women to generate networks of trust and gives them peace of mind in a broader context where they frequently experience discrimination. These daily experiences of national belonging do not result in a heightened sense of Bolivian values; they do not lead the women to openly confront the stigma of being Bolivian, or turn this stigma into an emblem of pride. Instead, they run parallel to these manifestations.

Their position as workers is also forged in their day-to-day interactions, at work, during time off, and even when they are out doing other things. In a particularly telling incident, Rodrigo (2018) remembers a group of Bolivian women from the soup kitchen taking a break during a protest in front of city hall in La Plata to check out some shop windows two blocks away. The leaders of the movement noticed their absence and brought up the incident at the next assembly. Wandering off in the middle of a protest, the leaders said, meant overlooking the reasons they had gotten organized in the first place. However, it is important to note that practices such as these contribute to these women's national and class identity bonds. Being in a part of the city where one doesn't usually go and enjoying a moment of recreation there serve to reinforce these bonds (Segura, 2015). Looking at shop windows can mobilize class aspirations, help gauge class distances (Caggiano, 2012a), and allow these women to update the criteria for accurately identifying fellow Bolivian women by the shoes they wear and by what they don't wear.

The social and political participation of the migrants from Altos de San Lorenzo rests on a national and class belonging that is interactive and domestic. As I noted earlier, these are based on experiences of Bolivian-ness and class, which differ from reaffirmations of nationality or class. Connections lay the foundations for these women's involvement in politics, making it an interactive, interpersonal process. ${ }^{8}$

There is a back-and-forth between the household and the organization, and the women filter these experiences. They take gender experiences that originate in early patriarchal contexts-experiences that initially enabled their work at the soup kitchen -as an extension of their caretaking responsibilities. Through dialogues with their peers, and the integration of new interpretive frameworks, they question and rework these experiences. The national and class belongings that exist in the day-to-day sustain their participation in the organization. They reformulate these belongings through their work at the organization and then continue to do so in their home and neighborhood.

\section{Politicizing Experience and the Dialectic between the Personal and the Political}

The cases analyzed here shed light on different levels of attributing meaning to experience and, more specifically, different levels of labeling experience as political. Women from these organizations have reinterpreted many of the practices and experiences of immigration and work from the new perspective activism has given them, prospectively and retrospectively considering aspects of their life based on the 
gender principles and criteria formulated there. On the other hand, non-politicized ways of living day-to-day lives-from the negotiations of domestic schedules and spaces to the identification of a fellow Bolivian by the clothing she wears-help define class or national belongings that are unquestionably political.

Though any facet of life can be politicized, politicization takes on different characteristics within the sphere of the home, on a slogan at the top of a flier, in a decree or law, or in discussions that can be one-on-one, with fellow activists, or among a group of religious believers. The political meaning of experience is built in dialogues between people and with social movements, sometimes from within, and with NGOs, state agencies, and international organizations. The varied, dynamic ways in which the political potential of experience is determined-be it gender or another kind of experience- can be attributed to the involvement of these different actors and their specific traits (legitimacy, authority, trust). The "imperfect alignments" and "mismatches" resulting from this dialogue often involve conflict.

The spheres of the home, the organizations, and state agencies, among others, are institutionalized to varying degrees and each have specific mechanisms for participation. They require specialist knowledge of their workings. Sometimes, as one member of Q'amasan noted, they require learning a discourse to the point of becoming "technical and theoretical." And specialist knowledge enables or requires translation. The exchanges, activities, and demands on immigrant women in one sphere impact and shape their position in others. Translating these from one area of life to the next is not always easy and, like any translation, requires them to adapt and reinvent.

The dynamic processes of politicization at different levels often create dilemmas. When confronted with labor exploitation at sweatshops run by fellow Bolivians, the Q'amasan activists do not employ the language of rights they use to reinterpret and guide their interventions in their personal gender experiences. In the past, personal ties led them to collaborate with an immigrant association accused of defending Bolivians who exploit their fellow countrymen and women in sweatshops (Caggiano, 2014). These ties, and a history of mutual collaboration, place them in an uncomfortable position both conceptually and politically. They believe that work conditions in the sweatshops should be evaluated on other terms. In a few words, these immigrant women treat human rights as a useful tool for assessing their gender experiences but as a potentially dangerous one when used in a social sphere like that of sweatshops. In their view, this tool can distort the reality there, which is governed by an entirely different logic.

Each sphere has its own particular hierarchy and its own inequalities. In some, for example, technical skills are valued, like accounting or the ability to draft funding applications in response to an international call for projects. In other situations, hazier values such as strength, perseverance, and determination are more prominent. Thus, although social leaders may celebrate women's strength when discussing their activism, some husbands, fathers, and brothers may also invoke this value to encourage a woman's work in the household and her fulfillment of what they consider her family responsibilities.

51 Time is of the essence in defining-and later, redefining-the profile of each organization. Each organization's involvement in different spheres affects the group trajectories and those of each of its members. When the gender perspective was incorporated to immigrant associations, it marked a shift in organizational outlooks at the beginning of this century. At the same time, it produced divisions and a regrouping 
based on supranational versus national identifications. In addition, the biographies of members have their own timing and rhythm, as revealed in Olivia's personal story, and can in turn influence those of other activists. Finally, time is also a factor that sheds light on the dynamic articulations of politicizing experience at different levels. The focus on sexual and reproductive health, sexual rights, or Christian solidarity and companionship when a fellow Bolivian woman is in trouble, are some of the myriad visions that can coexist simultaneously or within a short period of time. In some cases, a single woman may maintain both of these focuses for years, with the ensuing tensions this implies.

\section{Conclusions and Ramifications for a Study of Intersectionality}

When the experiences of immigrant women are politicized, the dialectic between the personal and the political unfolds. The cases of AMUMRA and Q'amasan clearly show the gender issue as a political grammar that articulates social experiences. The case of the soup kitchen provides more insight into how interpersonal gender experiences of immigrant women structure national and class grammars of the organization. In response to the question of "how sexual difference is itself articulated as a principle and practice of social organization" (Scott, 2000: 207), a range of possibilities opens on two extremes: a) a grammar of gender is introduced as a grid of intelligibility that allows (one's own) experiences and social practices to be interpreted and understood; and b) the daily ways in which we experience our gender relations quietly shape-and produce-demands that are explicitly organized in keeping with another grammar, that of class, nationality, or citizenship.

Immigrant women experience multiple types of oppression simultaneously. Different organizations often highlight one or more of these oppressions, creating tension in the way experiences are politicized. This is evident in the supranational approach to women's organizations promoted by certain international organizations and in nationality as a leitmotif guiding the actions of many immigrant women, who often choose to leave associations that opt for the first approach to join others dedicated exclusively to their fellow countrywomen. In the case of the MTD soup kitchen, whose leaders (Argentine women and men) generally do not reside in the neighborhood but whose volunteers are mostly Bolivian women, the issue that arose when the women slipped away from a protest for some window shopping reveals the profound tensions between gender, nationality, ethnicity, and class. These dynamic intersections are also transformed over the course of each woman's life, and as the organizations evolve.

As seen in this article, this complex process reveals how experience can be formally rendered political at different levels. Taking these levels into account has analytical repercussions for the study of inequalities from the lens of intersectionality.

The first is the following: even when certain lexicons, classification criteria, and categories are established and prove helpful at the organizational level, they by no means cover the full, knotty surface of experience. In this regard, it is important to note that experience is not an amorphous set of perceptions and feelings but articulates, to some degree, with other grammars learned in other spheres of life. Given the varied experiences of oppression, the possibilities of organizing it are also diverse. Local contexts and their specific situations pose challenges for generally established 
categories. This occurs, for example, when the immigrant women adopt the language of (gender) rights but interpret these rights critically-and even take a stance against them-when applied to particular situations like the work conditions at sweatshops run by fellow Bolivians. The interpretation and situated adaptation of lexicons, classification criteria, and categories is the usual mechanism that allows us to arrange and rearrange the grammars of our experience.

The second repercussion of considering the different levels of the politicization of experience is the acknowledgment that the dimensions of difference and inequality are never pure. Categories such as nationality, class, gender, and others are intertwined and mutually constitutive, and therefore, the challenge is to understand how class is gendered, how gender is classed, and so on (David, 2008: 71). By considering the different levels of the grammars of experience, it is possible to see how the nationality and class of women at the soup kitchen are gendered: nationality there means the Bolivian-ness of poor working women, and the class position is that of poor Bolivian working women. Nationality is inseparable from class and gender, just as social class is entwined with gender and nationality. On the other hand, the fieldwork offers an interesting account in this regard. At the beginning of 2000, some Bolivian seamstresses from local workshops began to note that immigrant organizations focusing on class, ethnic-national, or cultural belonging were not responding to concerns of theirs related to caregiving and household tasks. This shows that the class, ethnicitynationality, and culture of these organizations are also gendered, i.e., masculinized. "Asking the other question" (Matsuda, 1991, quoted in Davis, 2008) does not mean adding dimensions, then, but understanding how the dimensions are intertwined and mutually define one another.

The third analytical consequence of considering how experience is rendered political at different levels is that when the grammars are suitably managed, they can influence existing power relations. The most visible power inequality in the analyzed cases is the sway international organizations and state agencies hold over social organizations when it comes to defining agendas, issues, and the language used to address them. Yet this is about more than a simple imposition: the need to navigate these grammars becomes an opportunity to reposition oneself more favorably. None of these processes are one-directional. Grassroots organizations also carve out space in the negotiations with state agencies and international organizations to voice their interests and define a modus operandi, categories, and agendas (Østergaard-Nielsen, 2003).

In summary, although certain grammars of experience may be enshrined and even institutionalized, this does not eradicate other dimensions of inequality or difference, nor does it definitively impose one of these dimensions over the others. An awareness of the different levels at which experience is politicized, and its bearing on the intersection of inequalities, can provide an analytical approach to unraveling intersectionality. 


\section{BIBLIOGRAPHY}

Alcoff Linda (2000) Merleau-Ponty and Feminist Theory of Experience, in Chiasms: Merleau-Ponty's Notion of Flesh, Fred Evans and Leonard Lawlor Eds., Albany, Albany State University of New York Press, pp. 251-272.

Arizpe Lourdes (1987) Prólogo, in Elizabeth Jelin Ed., Ciudadanía e identidad: las mujeres en los movimientos sociales latino-americanos, Ginebra, UNSRID, pp. 11-19.

Caggiano Sergio (2014) Desigualdades entrelazadas, luchas divergentes: migración e industria textil en Argentina, Revista CIDOB d'Afers Internacionals, 106-107, pp. 151-170.

Caggiano Sergio (2012a) Conexões e entrecruzamentos: Configurações culturais e direitos em um circuito migratório entre La Paz e Buenos Aires, Mana - Estudos de Antropologia Social, 18 (1) pp. 63-90.

Caggiano Sergio (2012b) El sentido común visual. Disputas en torno a género, raza y clase en imágenes de circulación pública, Buenos Aires, Miño y Dávila editores.

Caldeira Teresa (1987) Mujeres, cotidianeidad y política, in Elizabeth Jelin Ed., Ciudadanía e identidad: las mujeres en los movimientos sociales latino-americanos, Geneva, United Nations Research Institute for Social Development, pp. 47-78.

Cerrutti Marcela (2010) Informe Final del Proyecto Migración y Salud Sexual y reproductiva de las Mujeres y de los Jóvenes Bolivianos en la Argentina, Buenos Aires, UNFPA-Centro de Estudios de Población y Consejo Nacional de Investigaciones Científicas y Técnicas.

Chung Angie Y. (2005) "Politics without the politics": The evolving political cultures of ethnic non-profits in Koreatown, Los Angeles, Journal of Ethnic and Migration Studies, 31 (5), pp. 911-929.

Courtis Corina and Pacecca María Inés (2010) Género y trayectoria migratoria: mujeres migrantes y trabajo doméstico en el Área Metropolitana de Buenos Aires, Papeles de Población, 16 (63), pp. 155-185.

Davis Kathy (2008) Intersectionality as buzzword. A sociology of science perspective on what makes a feminist theory successful, Feminist Theory, 9 (1), pp. 67-85.

Donato Katharine M., Gabaccia Donna, Holdaway Jennifer, Manalansan Martin and Pessar Patricia R. (2006) A glass half full? Gender in migration studies, International Migration Review, 40 (1), pp. 3-26.

Elizalde Silvia (2008) Debates sobre la experiencia. Un recorrido por la teoría y la praxis feminista, Oficios Terrestres, 23, pp. 18-30.

Erel Umut, Morokvasic Mirjana and Shinozaki Kyoko (2003) Introduction. Bringing gender into migrational, in Umut E., Morokvasic M. and Shinozaki K. Eds., Crossing Borders and Shifting Boundaries. Vol I: Gender on the Move, Wiesbaden, Springer, pp. 9-22.

Goldring Luin (2001) The gender and geography of citizenship in Mexico-US transnational spaces, Identities: Global Studies in Culture and Power, 74, pp. 501-537.

GRDR (2016) Entre renouvellement des instances de gouvernance et émergence de dynamiques organisationnelles autonomes : quelles modalités pour l'engagement associatif des jeunes, descendants d'immigrés d'origine subsaharienne?, Rapport FVDA janvier 2016, Paris, Ministère de la Ville, de la Jeunesse et des sports/Université Paris 8 Vincennes-Saint-Denis/FORIM, 76 p. 
Guillaumin Colette (1992) Sexe, Race et Pratique du pouvoir. L'idée de Nature, Paris, Côtéfemmes, 240 p.

Haraway Donna (1989) Primate Visions. Gender, Race, and Nature in the World of Modern Science, New York, Routledge.

Hardy-Fanta Carol (1993) Latina Politics, Latino Politics: Gender, Culture, and Political Participation in Boston, Philadelphia, Temple University Press.

Herrera Gioconda (2013) Gender and International Migration: Contributions and CrossFertilizations, Annual Review of Sociology, 39, pp. 1-19.

Hondagneu-Sotelo Pierrette (2011) Estudios de género y migración: Una revisión desde la perspectiva del siglo xxi, Migraciones Internacionales, 6 (20), pp. 219-233.

hooks Bell (2000) Feminist Theory: From Margin to Center, London, Pluto Press.

Instituto Nacional de Estadística y Censos (INDEC) (2003) Encuesta Complementaria de Migraciones Internacionales, [online] Accessed 12/15/2012. URL: https://www.indec.gov.ar/ micro_sitios/webcenso/ECMI/index_ecmi.asp

International Organization for Migration (IMO) and Centro de Estudios Migratorios Latinoamericanos (CEMLA) (2004) Relevamiento y diagnóstico de las Asociaciones de la comunidad boliviana en la Argentina. Informe Final, Buenos Aires, OIM-CEMLA.

Jay Martin (2005) Songs of Experience: Modern American and European Variations on a Universal Theme, Berkeley, University of California Press.

Jay Martin (1998) The crisis of experience in a post-subjective age, public lecture, University of California Berkeley, November 14, 1998.

Jelin Elizabeth (Dir.) (2006) Salud y migración regional: Ciudadanía, discriminación y comunicación intercultural, Buenos Aires, IDES, $119 \mathrm{p}$.

Kuah-Pearce Kuhn Eng and Hu-Dehart Evelyn (2006) Introduction: The Chinese Diaspora and Voluntary Associations, in Khun Eng Kuah-Pearce and Evelyn Du-Dehart Eds., Voluntary Organizations in the Chinese Diaspora, Hong Kong, Hong Kong University Press, pp. 1-28.

Long Norman (1999) The multiple optic of interface analysis, background paper on interface analysis, UNESCO.

Low Angeline (2006) The roles and contributions of Chinese women entrepreneurs in community organizations in Sydney, in Khun Eng Kuah-Pearce and Evelyn Du-Dehart Eds., Voluntary Organizations in the Chinese Diaspora, Hong Kong, Hong Kong University Press, pp. 201-230.

Magliano María José (2013) Los significados de vivir múltiples presencias: Mujeres bolivianas en Argentina, Migraciones Internacionales, 7 (1), pp. 165-195.

Magliano María José (2009) Las migraciones de las mujeres bolivianas: proyectos familiares, roles de género y experiencias migratorias en Córdoba, in María José Magliano and Ana Inés Mallimaci Eds., Las mujeres latinoamericanas y sus migraciones, Villa María, Eduvim, pp. 47-61.

Mallimaci Ana Inés (2009) Migraciones y género. Las formas de la visibilidad femenina, in María José Magliano and Ana Inés Mallimaci Eds., Las mujeres latinoamericanas y sus migraciones, Villa María, Eduvim, pp. 11-25.

Mira María Celeste (2003) O masculino e o femenino nas narrativas da cultura de masas ou o deslocamento do olhar, Cadernos Pagu, 21, pp. 13-38. 
Navaro-Yashin Yael (2009) Affective spaces, melancholic objects: ruination and the production of anthropological knowledge. Journal of the Royal Anthropological Institute (N.S.), 15, pp. 1-18.

Østergaard-Nielsen Eva (2003) The Politics of Migrants' Transnational Political Practices, International Migration Review, 37 (3), pp. 760-786.

Pérez Alberto Martín (2004) Las asociaciones de inmigrantes en el debate sobre las nuevas formas de participación política y de ciudadanía: reflexiones sobre algunas experiencias en España, Migraciones, 15, pp. 113-143.

Pessar Patricia R. (2005) Women, gender and international migration across and beyond the Americas: inequalities and limited empowerment, Expert Group Meeting on International Migration and Development in Latin America and the Caribbean, Population Division Department of Economic and Social Affairs United Nations Secretariat.

Piper Nicola (2006) Gendering the Politics of Migration, International Migrations Review, 40 (1), pp. 133-164.

Poole Deborah (2000) Visión, raza y modernidad. Una economía visual del mundo andino de imágenes, Lima, Sur Casa de Estudios del Socialismo y Consejería en Proyectos.

Rodrigo Federico (2018) Género y nacionalidad en la cotidianidad de la política Migrantes bolivianas en un movimiento piquetero de la ciudad de La Plata, Buenos Aires, Miño y Dávila.

Sassen Saskia (2003) Contrageografías de la globalización. Género y ciudadanía en los circuitos transfronterizos, Madrid, Traficantes de Sueños.

Schnapper Dominique (1988) Modernidad y aculturaciones a propósito de los trabajadores emigrantes, in Tzvetan Todorov Ed., Cruce de culturas y mestizaje cultural, Madrid, Jucar, pp. 173-205.

Scott Joan W. (1992) Experience, in Feminists Theorize the Political, Judith Butler and Joan W. Scott Eds. New York, Routledge, pp. 22-40.

Scott Joan (2000) Some more reflections on gender and politics, in Joan Scott, Gender and the politics of history, New York, Columbia University Press, pp. 199-222.

Segura Ramiro (2015) Vivir afuera: Antropología de la experiencia urbana, San Martín, UNSAM EDITA. Sinisi Liliana (1999) La relación nosotros-otros en espacios escolares multiculturales. Estigma, estereotipo y racialización, in María Rosa Neufeld and Ariel Thisted Jens Eds., De eso no se habla... los usos de la diversidad sociocultural en la escuela, Buenos Aires, Eudeba, pp. 189-234.

Sinisi Liliana (1998) “Todavía están bajando del cerro". Condensaciones estigmatizantes de la alteridad en la cotidianeidad escolar, $1^{\mathrm{er}}$ Congreso Virtual de Antropología y Arqueología, [online] Accessed 07/31/2009. URL: http://www.naya.org.ar/congreso/ponencia2-2.htm

Smith Shawn Michelle (1999) American Archives. Gender, Race, and Class in Visual Culture, New Jersey, Princeton University Press.

Stolcke Verena (1992) Racismo y sexismo en la Cuba colonial, Madrid, Alianza Editorial.

Stone-Mediatore Shari (1999) Chandra Mohanty y la revalorización de la "experiencia"5, Revista Hiparquia, 10 (1), pp. 85-109.

Yuval-Davis Nira, Anthias Floya and Kofman Eleonore (2005) Secure borders and safe haven and the gendered politics of belonging: Beyond social cohesion, Ethnic and Racial Studies, 28 (3), pp. 513-535. 


\section{NOTES}

1. The notion has allowed novel aspects of migration to be captured (Courtis and Pacceca, 2010), even in processes of "family" migration, like that of Bolivians to Argentina (Cerrutti, 2010). Nonetheless, the decontextualized use of the notion and the reification of European research have led certain aspects of family migratory projects within the Southern hemisphere to be overlooked (Mallimaci, 2009). For a panoramic look at the research into migratory processes from a gender perspective and their main focuses, see Erel et al. (2003), Hondagneu-Sotelo (2011) and Herrera (2013).

2. While these are the actual names of the associations, I have used pseudonyms for their members to protect their privacy.

3. As part of a long-term empirical study on Bolivian migrations to Argentina, my ethnographic fieldwork with immigrant women has involved organizations in Argentina's capital, Buenos Aires, and La Plata, the capital of the province of Buenos Aires. The fieldwork, which took place in stages (2005, 2009, 2012 and 2015), brought me in touch with the first two of the associations. In my dealings with the organizations, I carried out a total of 28 individual and groups interviews. My fieldwork also involved participating and observing meetings among activists and between activists, state officials, and representatives from international organizations, as well as attending activities open to the community in which the associations participated. With four of the activists, I was able to carry out periodical interviews over the years, allowing for a diachronic reconstruction of their trajectories. For the community soup kitchen case, I draw on an ethnography by Federico Rodrigo that I supervised. The fieldwork consisted of weekly visits to the soup kitchen between April 2010 and March 2012, with participant observation at its meetings, work sessions, and the actions organized by the MTD to discuss their demands. Rodrigo held interviews with 15 Bolivian women at the soup kitchen and four of the Argentine coordinators.

4. CAREF is a lay organization sponsored by the Río De La Plata Evangelical Church, the Discípulos de Cristo Evangelical Church, the Evangelist-Methodist Church of Argentina, and the Anglican Dioceses of Argentina.

5. The age and years of residence of each informant correspond to the moment of the interview. 6. As noted earlier, the analysis of this third case is based on an ethnography by Rodrigo (2018). Seventy kilometers south of the city of Buenos Aires, La Plata is the capital of the province of Buenos Aires. Located on a stretch of the urban periphery that developed much later than the rest of that city, Altos de San Lorenzo is a socially heterogeneous neighborhood on the opposite end of La Plata's most developed area (Segura, 2015).

7. This program, which is run by Argentina's National Ministry of Social Development and different state agencies (municipal or provincial administrations, labor federations and/or mutual societies), targets people with no formal income. The idea is for small groups to form cooperatives that then carry out local public works.

8. As Hardy-Fanta (1993) described for Latinas in Boston, these forms of political participation do not reflect the classical theory of politics that draws exclusively on masculine experiences and is associated with public life, hierarchies, and measurable behaviors such as voting. Yet it would be mistaken to consider these political spaces dichotomous; they interact with one another, each with their own specific features. Thus, just as the official, masculine politics Hardy-Fanta analyzes cannot be thought of without the cooperation and community networks forged by Latin women, the Bolivian women's networks, once established, allow for a public affirmation of national and class belongings embodied almost exclusively by men. 


\section{ABSTRACTS}

This article explores the incorporation of gender issues by associations of migrant women in Argentina, in the first years of the XXI century. The main question is how the experiences of migrant women are politically articulated. The process shows the existence of different levels of political formalization of experience. The politicization of experience takes different forms, which may be complementary or discrepant, at home, in a political organization, in the streets, in a state or supra-state institution. Concepts, points of view and knowledge circulate among actors with specific capitals and asymmetric negotiation capacities. The politicization of experience at different levels helps to understand how social positions coexist, are assembled and hierarchized, and is, therefore, an analytical gateway for the study of intersectionality.

L'article explore la prise en compte de la problématique du genre par les associations de femmes migrantes en Argentine dans les premières années du XXIe siècle. La question principale est de savoir comment s'articulent politiquement les vécus des femmes migrantes. Au foyer, dans une organisation politique, dans les rues, dans une institution nationale ou supranationale la politisation de l'expérience prend différentes formes, qui peuvent être complémentaires ou bien divergentes. Concepts, points de vue et savoirs circulent entre acteurs aux capitaux spécifiques et capacités de négociation asymétriques. La politisation de l'expérience à différents niveaux aide à comprendre comment les positions sociales coexistent, s'assemblent et se hiérarchisent, et constitue donc une porte d'entrée analytique pour l'étude de l'intersectionnalité.

El artículo explora la incorporación de la problemática de género por parte de asociaciones de mujeres migrantes en Argentina en los primeros años del siglo XXI. La pregunta principal es cómo se articulan las vivencias de las mujeres migrantes en clave política. El análisis permite ver la existencia de diferentes niveles de formalización política de la experiencia. En el hogar, en una organización política, en las calles, en una institución estatal o supraestatal la politización de la experiencia toma formas diferentes, complementarias o discrepantes. Conceptos, puntos de vista y saberes circulan entre actores con capitales específicos y capacidades de negociación asimétricas. La politización de la experiencia en distintos niveles ayuda a comprender cómo conviven, se ensamblan y jerarquizan posiciones sociales y resulta, entonces, una puerta de entrada analítica para el estudio de la interseccionalidad.

\section{INDEX}

Palabras claves: mujeres migrantes, organizaciones sociales, experiencia, género, política Mots-clés: femmes migrantes, organisations sociales, expériences, genre, politique Keywords: migrant women, social organizations, experience, gender, politics

\section{AUTHORS}

\section{SERGIO CAGGIANO}

Independent Researcher. Centro de Investigaciones Sociales (CIS), Consejo Nacional de Investigaciones Científicas y Técnicas (CONICET), Instituto de Desarrollo Económico y Social (IDES), Aráoz 2838, Buenos Aires, Argentina; sergio.caggiano[at]gmail.com 